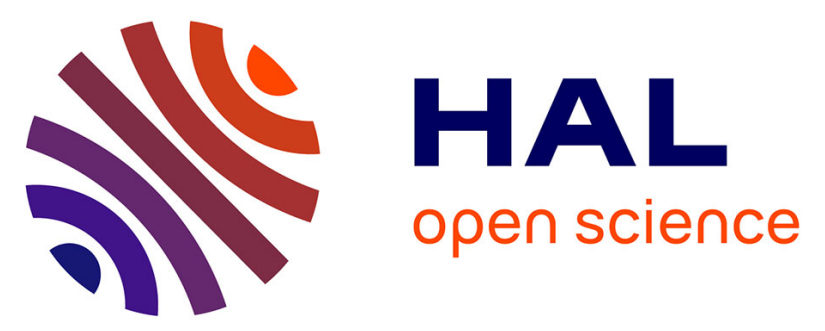

\title{
Oral melanosis and severe periodontitis in toombak case report
}

\author{
Badr Abdullah Saeed Al-Tayar, Mon Mon Tin-Oo, Mohd Zulkarnain Sinor, \\ Mohamed Hussein Abdikarim, Mohammed Sultan Al-Ak'Hali
}

\section{To cite this version:}

Badr Abdullah Saeed Al-Tayar, Mon Mon Tin-Oo, Mohd Zulkarnain Sinor, Mohamed Hussein Abdikarim, Mohammed Sultan Al-Ak'Hali. Oral melanosis and severe periodontitis in toombak case report. European Journal of Medical Case Reports, 2017, 2 (1), pp.9-11. 10.24911/ejmcr/1/35 . hal-03158560

\section{HAL Id: hal-03158560 https://hal.science/hal-03158560}

Submitted on 4 Mar 2021

HAL is a multi-disciplinary open access archive for the deposit and dissemination of scientific research documents, whether they are published or not. The documents may come from teaching and research institutions in France or abroad, or from public or private research centers.
L'archive ouverte pluridisciplinaire HAL, est destinée au dépôt et à la diffusion de documents scientifiques de niveau recherche, publiés ou non, émanant des établissements d'enseignement et de recherche français ou étrangers, des laboratoires publics ou privés. 
Discover STM Publishing

- Submit a Manuscript

- Guide For Authors

European Journal of Medical Case Reports

Home

- Current Issue

- Latest Articles

- Archives

- About

- Aims \& Scope

- Editorial Board

- Subscribe

«Previous Article

Next Article »

\section{Case Report}

EJMGR. 2018; 2(January 2018): 9-11

doi: 10.24911/ejmcr/1/35

European Journal of Medical Case Reports

Volume 2(1):9-11

(c) EJMCR

10.24911/ejmcr/1/35

Oral melanosis and severe periodontitis in toombak 


\section{users: a case report}

Badr Abdullah Saeed Al-Tayar ${ }^{{ }^{*}}$, Mon Mon Tin-Oo ${ }^{2}$, Mohd Zulkarnain Sinor ${ }^{2}$, Mohamed Hussein Abdikarim ${ }^{3}$, Mohammed Sultan Al-ak'hali 4

Received: 12 September 2017 | Accepted: 16 October 2017

Type of Article: CASE REPORT

Funding: None

Declaration of conflicting interests: None

\section{Corresponding Author:}

Badr Abdullah Saeed Al-Tayar

${ }^{*}$ Community Dentistry, School of Dental Sciences, Universiti Sains Malaysia, Health Campus, Kubang Kerian, Kelantan, Malaysia.

Email: bader2221 [at] windowslive.com

\section{ABSTRACT}

Background: Toombak is a traditional type of smokeless tobacco used by people in Yemen, especially in Dawan Valley, Hadramout Province, Yemen. The use of smokeless tobacco may be considered as a predisposing risk factor for several oral diseases.

Case Presentation: This paper presents two cases. The first is that of a 27 -year-old male toombak user with severe periodontitis and oral melanosis. The second case is that of a 44year-old male toombak user with oral hypermelanosis. The patients were subjected to dental cleaning. Quit toombak counseling was conducted, and the patients were educated about the adverse effects of toombak usage.

Conclusion: Oral tissues are severely affected by toombak usage. Thus, comprehensive toombak prevention programs should be implemented to reduce toombak-associated diseases.

Keywords: Toombak, smokeless tobacco, melanosis, periodontitis, case report.

\section{Background}

In Yemen, several varieties of smokeless tobacco are widely used, including shammah, tombol, and toombak. Toombak is commonly used in Dawan Valley, Yemen. It is composed of sun- 
dried powdered tobacco leaves mixed with ash [ 1] ( Figure 1). Toombak is usually placed in the buccal lower or labial vestibules [2], as shown in Figure 2. The association between traditional types of smokeless tobacco in Yemen and the development of oral diseases has been rarely considered.

Al-Tayar et al. presented the periodontal status of 346 Yemenis in Dawan Valley, Yemen. In their study, multiple logistic regression analysis revealed that regular toombak users were 6.62 times more likely to develop periodontal pocket than those who had never used it [ 1].

As regards toombak-induced alterations in oral mucosal tissues, Al-Tayar et al. [ 3] found that the participants who were using toombak at the time were almost 13 times more likely to develop oral leukoplakia-like lesions than those who had never used it. In terms of oral mucosal melanosis, several studies have confirmed the association between smoking and such lesion [ 4] but not with smokeless tobacco. However, Naveen-Kumar et al. [ 5] observed tobacco-associated melanosis most frequently in conventional smokers, followed by reverse smokers and smokeless tobacco group. Current clinical reports describe various intraoral findings that suggest the oral mucosal changes and the degenerative and destructive magnitude of periodontal tissues in patients with toombak use history of more than 8 years.

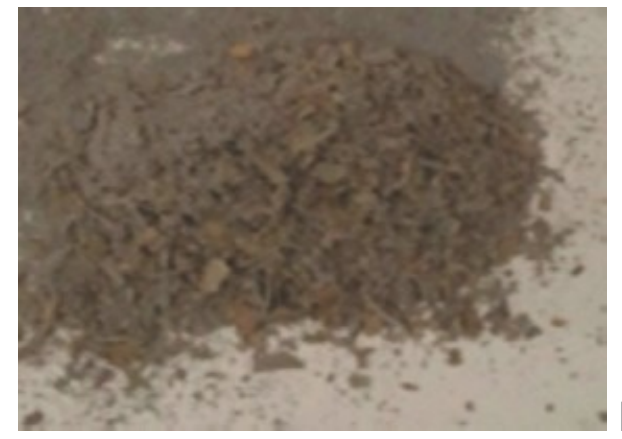

Figure 1: Toombak

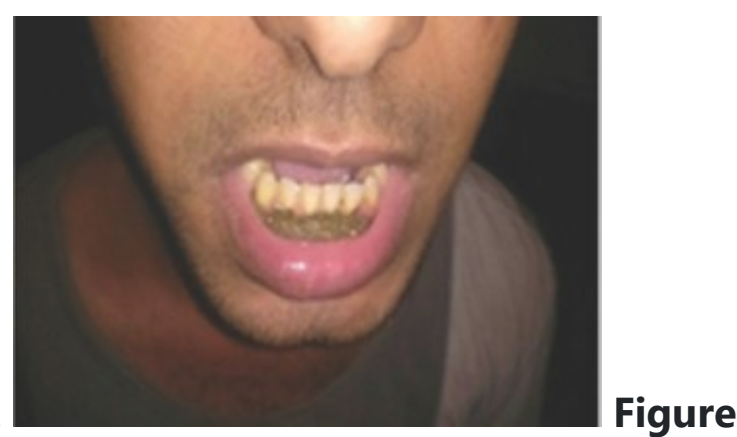

2: Toombak in the lower labial vestibule of the oral cavity.

\section{Case Presentation}

The first case is of a 27-year-old male who visited Al-Ebtessamah Dental Clinic in Dawan Valley, Yemen, with the chief complaint of pain in the lower gum from the right to left canine region. The patient was a toombak user for more than 8 years. His habitual placement of toombak was on the lower right muco-buccal vestibule and sometimes on the lower labial vestibule. Clinical examinations showed severe deposition of dental calculus and grade III mobility of mandibular left central incisor and mandibular right canine. Periodontal probing 
revealed a pocket depth ranging from 6 to $10 \mathrm{~mm}$ in the mandibular anterior region. Oral mucosal pigmentation was found on the site of habitual toombak placement ( Figure 3). The case was diagnosed as chronic periodontitis and oral mucosal melanosis induced by extraction was planned for the mandibular left central incisor and mandibular right canine. The patient was also subjected to planned sessions of scaling and root planning and was instructed to maintain good oral hygiene. Analgesic and chlorhexidine mouthwash were prescribed.

Quit toombak counseling was conducted, and the patient was educated about the adverse effects of toombak usage.

The second case is of a 44-year-old male who presented to the Al-Ebtessamah Dental Clinic in Dawan Valley, Yemen, with a complaint of mandibular anterior teeth discoloration with black pigmentation on the lower anterior muco-labial vestibule ( Figure 4). Toombak use history was 8.5 years. The pigmentation was found on the lower anterior muco-labial vestibule where the patient typically placed the toombak. The changes were asymptomatic. This pigmentation was clinically diagnosed as oral melanosis aggravated by long-term toombak usage. The patient was subjected to scaling and polishing. Quit toombak counseling was conducted, and the patient was educated about the adverse effects of toombak usage.

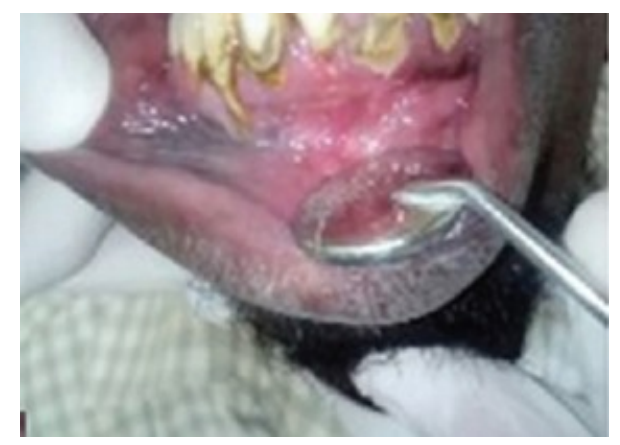

Figure 3: Chronic periodontal destruction and changes of

oral melanosis at lower right muco-buccal vestibule.

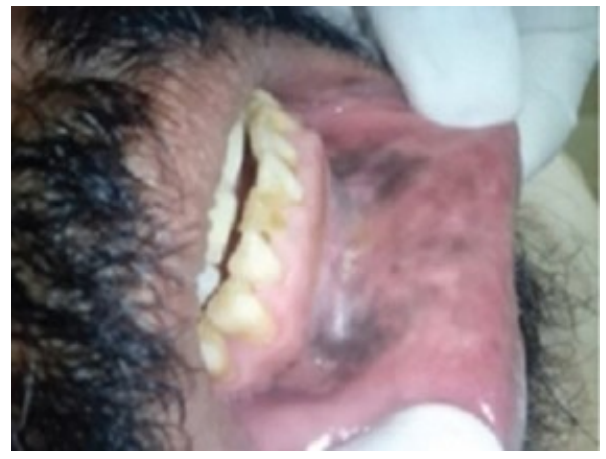


4: Changes of oral melanosis at lower anterior muco-labial vestibule.

\section{Discussion}

The reported cases involved advanced loss of periodontal tissues obviously related to toombak usage of more than 8 years. A possible contributing mechanism in the development of severe periodontal disease is the cholinergic effect of toombak along with the calcium salt in the saliva produced during hypersalivation causing calculus deposition. The heavy calculus deposition can then destroy periodontal tissue in smokeless tobacco users [6]. This finding is confirmed by a case report presented by Giri et al. [ 7], which showed that smokeless tobacco in the form of betel nut chewing is associated with advanced periodontal tissue loss. The present case report is also supported by the study of Parmar et al. [ 8], which revealed the significantly higher development of periodontal pockets and gingival recession in smokeless tobacco users than in non-users.

The color change of the oral mucosa is due to the accumulation of one or more tissue pigments. The pigments associated with mucosal discoloration could be classified as endogenous, such as melanin pigments, and exogenous, such as drug-related pigments. Melanin-associated lesions are the most common pigmentations. Both the smoked and smokeless forms of tobacco induce oral mucosal changes, among which intraoral mucosal pigmentation is a clinical manifestation [9]. Tobacco use, especially smoking, may augment melanin production, which may provide a biological defense against the noxious agents present in tobacco smoke [ 10]. Our report stated that toombak may induce oral melanosis. This result is supported by the report of Kumar and Chaturvedi [ 11], which revealed brown pigmentation in the ventral aspect of the tongue of a patient who used smokeless tobacco, specifically, chewing tobacco, for 6 years.

\section{Conclusion}

Toombak affects the oral tissues of its users. Thus, comprehensive toombak prevention programs should be implemented to reduce toombak-associated diseases.

\section{Acknowledgement}

The authors acknowledge the staff at the Al-Ebtesammah Dental Clinic in Dawan Valley, Yemen, who helped to collect patient data and images. 


\section{List of Abbreviations}

None

\section{Consent for publication}

Informed consent was obtained from the patients to publish this case.

\section{Ethical approval}

Ethical approval is not required at our institution for publishing a case report in a medical journal.

\section{Author details}

Badr Abdullah Saeed Al-Tayar ${ }^{1}$, Mon Mon Tin Oo ${ }^{2}$, Mohd Zulkarnain Sinor ${ }^{2}$, Mohamed Hussein Abdikarim ${ }^{3}$, Mohammed Sultan Al-ak'hali ${ }^{4}$

1. Community Dentistry, School of Dental Sciences, Universiti Sains Malaysia, Health Campus, Kubang Kerian, Kelantan, Malaysia

2. Dental Public Health, School of Dental Sciences, Universiti Sains Malaysia, Health Campus, Kubang Kerian, Kelantan, Malaysia

3. Biomedicine Program, School of Health Sciences, Universiti Sains Malaysia, Health Campus, Kubang Kerian, Kelantan, Malaysia

4. Faculty of Dentistry, Jazan University, Saudi Arabia

\section{References}

1. Al-Tayar B, Tin-Oo MM, Sinor MZ, Alakhali MS. Prevalence and association of smokeless tobacco use with the development of periodontal pocket among adult males in Dawan Valley, Yemen: a cross-sectional study. Tob Induc Dis 2015; 13:35 https://doi:10.1186/s12971-015-0061-8

2. Salem G. Leukoplakia and tobacco habits in Gizan, Saudi Arabia. Saudi Dent J 1992; 4(2):50-4.

3. Al-Tayar BA, Tin-Oo MM, Sinor MZ, Alakhali MS. Association between Shammah use and oral leukoplakia-like lesions among adult males in Dawan Valley, Yemen. Asian Pac J Cancer Prev 2015; 16:8365-70. https://doi:10.7314/APJCP.2015.16.18.8365 
4. Tadakamadla J, Kumar S, Nagori A, Tibdewal H, Duraiswamy P, Kulkarni S. Effect of smoking on oral pigmentation and its relationship with periodontal status. Dent Res J (Isfahan) 2012; 9(Suppl 1):S112-4.

5. Naveen-Kumar B, Tatapudi R, Sudhakara-Reddy R, Alapati S, Pavani K, Sai-Praveen KN. Various forms of tobacco usage and its associated oral mucosal lesions. J Clin Exp Dent 2016; 8:172-7. https://doi:10.4317/jced.52654

6. Ling LJ, Hung SL, Tseng SC, Chen YT, Chi LY, Wu KM, et al. Association between betel quid chewing, periodontal status and periodontal pathogens. Oral Microbiol Immunol 2001; 16(6):364-9. https://doi:10.1034/j.1399-302X.2001.160608.x

7. Giri DK, Kundapur P, Bhat K, Maharjan I. Betel nut chewing associated with severe periodontitis. Health Renaissance 2015; 12(1):57-60. https://doi:10.3126/hren.v12i1.11990

8. Parmar G, Sangwan P, Vashi P, Kulkarni P, Kumar S. Effect of chewing a mixture of areca nut and tobacco on periodontal tissues and oral hygiene status. J Oral Sci 2008; 50(1):57-62. https://doi.org/10.2334/josnusd.50.57

9. Mirbod SM, Ahing SI. Tobacco-associated lesions of the oral cavity: Part I. Nonmalignant lesions. J Can Dent Assoc 2000; 66(5):252-6.

10.Hedin C, Pindborg JJ, Daftary D, Mehta F. Melanin depigmentation of the palatal mucosa in reverse smokers: a preliminary study. J Oral Pathol Med 1992; 21(10):440-4. https://doi:10.1111/j.1600-0714.1992.tb00971.x

11.Kumar H, Chaturvedi P. Oral melanosis. Int J Head Neck Surg 2011; 2(2):121-3. https://doi:10.5005/jp-journals-10001-1065

\section{Summary of the case}

\section{Patient (gender,} age)

1 Males, 27 and 44 years old

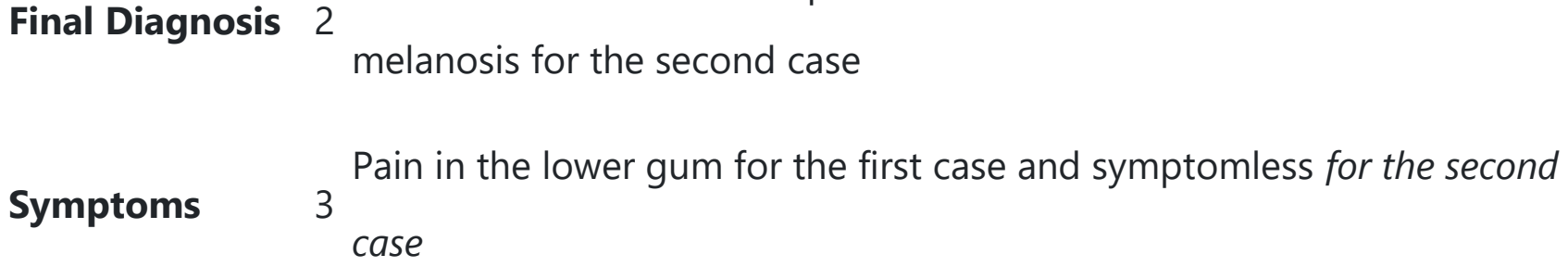

Medications 4 Analgesic and chlorhexidine mouthwash for the first case and no 
medications for the second case.

Clinical

Procedure

Specialty $\quad 6$ Dental Public Health

\section{How to Cite this Article}

\section{Pubmed Style}

Badr Abdullah Al-Tayar, Mon Mon Tin-Oo, Mohd Zulkarnian Sinor, Mohamed Hussein Abdikarim, Mohammed Sultan Al-akhali. Oral melanosis and severe periodontitis in toombak users: a case report. EJMCR. 2018; 2(January 2018): 9-11. doi:10.24911/ejmcr/1/35

\section{Web Style}

Badr Abdullah Al-Tayar, Mon Mon Tin-Oo, Mohd Zulkarnian Sinor, Mohamed Hussein Abdikarim, Mohammed Sultan Al-akhali. Oral melanosis and severe periodontitis in toombak users: a case report. https://www.ejmcr.com/?mno=277685 [Access: January 14, 2020]. doi:10.24911/ejmcr/1/35

\section{AMA (American Medical Association) Style}

Badr Abdullah Al-Tayar, Mon Mon Tin-Oo, Mohd Zulkarnian Sinor, Mohamed Hussein Abdikarim, Mohammed Sultan Al-akhali. Oral melanosis and severe periodontitis in toombak users: a case report. EJMCR. 2018; 2(January 2018): 9-11. doi:10.24911/ejmcr/1/35 
Badr Abdullah Al-Tayar, Mon Mon Tin-Oo, Mohd Zulkarnian Sinor, Mohamed Hussein Abdikarim, Mohammed Sultan Al-akhali. Oral melanosis and severe periodontitis in toombak users: a case report. EJMCR. (2018), [cited January 14, 2020]; 2(January 2018): 9-11. doi:10.24911/ejmcr/1/35

\section{Harvard Style}

Badr Abdullah Al-Tayar, Mon Mon Tin-Oo, Mohd Zulkarnian Sinor, Mohamed Hussein Abdikarim, Mohammed Sultan Al-akhali (2018) Oral melanosis and severe periodontitis in toombak users: a case report. EJMCR, 2 (January 2018), 9-11. doi:10.24911/ejmcr/1/35

\section{Turabian Style}

Badr Abdullah Al-Tayar, Mon Mon Tin-Oo, Mohd Zulkarnian Sinor, Mohamed Hussein Abdikarim, Mohammed Sultan Al-akhali. 2018. Oral melanosis and severe periodontitis in toombak users: a case report. European Journal of Medical Case Reports, 2 (January 2018), 9-11. doi:10.24911/ejmcr/1/35

\section{Chicago Style}

Badr Abdullah Al-Tayar, Mon Mon Tin-Oo, Mohd Zulkarnian Sinor, Mohamed Hussein Abdikarim, Mohammed Sultan Al-akhali. "Oral melanosis and severe periodontitis in toombak users: a case report." European Journal of Medical Case Reports 2 (2018), 9-11. doi:10.24911/ejmcr/1/35

\section{MLA (The Modern Language Association) Style}


Abdikarim, Mohammed Sultan Al-akhali. "Oral melanosis and severe periodontitis in toombak users: a case report." European Journal of Medical Case Reports 2.January 2018 (2018), 9-11. Print. doi:10.24911/ejmcr/1/35

\section{APA (American Psychological Association) Style}

Badr Abdullah Al-Tayar, Mon Mon Tin-Oo, Mohd Zulkarnian Sinor, Mohamed Hussein Abdikarim, Mohammed Sultan Al-akhali (2018) Oral melanosis and severe periodontitis in toombak users: a case report. European Journal of Medical Case Reports, 2 (January 2018), 9-11. doi:10.24911/ejmcr/1/35

Journal

- Thank you to our reviewers

- Editorial \& Peer Review Process

- Publishing Ethics

- Abstracting \& indexing

- Reviewer Login

- About Publisher

Authors

- Instructions for authors

- Author's Rights and Obligations

- Self-Archiving Policies

- Submit an article

- Track your Article

Help

- Contact us

- Disclaimer

- Advertising 
- Privacy \& Cookies

- Sitemap (XML)

Download

- Sample CARE-checklist

- CARE-checklist

- Patient Consent Form (WORD doc)

- Patient Consent Form (pdf)

Policies

- Editorial Policies

- Publication Ethics and Publication Malpractice Statement

- Conflict of Interest Policy

- Plagiarism Policy

- Protection of Research Participants

- Website Terms \& Conditions

Disclaimer

$\times$

Although every effort is made by the Editorial Board of the concerned journals and the publisher (Discover Publishing Group) to see that no inaccurate or misleading data, opinion or statement appear in the journal(s) or websites managed or published by Discover Published Group, we want to make it clear that the data and opinions appearing in the articles and advertisements herein are the responsibility of the contributors, sponsors, or advertisers concerned. Accordingly, the Publisher and the Editorial Boards disclaim all responsibilities for the consequences of any such inaccurate or misleading data, opinion, or statement. To the extent permissible under applicable laws, no responsibility is assumed by the Publisher nor by the Editors for any injury and/or damage to persons or property as a result of any actual or alleged libellous statements, infringement of intellectual property or privacy rights, or products liability, whether resulting from negligence or otherwise, or from any use or operation of any ideas, instructions, procedures, products or methods contained in the material therein. Whilst every effort is made to ensure that drug doses and other quantities are presented accurately, readers are advised that new methods and techniques involving drug usage, and described in DPG journals, should only be followed in conjunction with the drug manufacturer's own published literature in their own country. 
